\title{
Parametric design applied to die cutting machine
}

\section{Diseño paramétrico aplicado a una máquina Suajadora}

JARA-RUIZ, Ricardo $\dagger^{*}$, DE LA CRUZ, Jesús, RODRÍGUEZ-FRANCO, Martín Eduardo and DELGADO-GUERRERO, Sergio Humberto

Universidad Tecnológica del Norte de Aguascalientes. Av. Universidad No. 1001, Estación Rincón, Rincón de Romos, Ags. C.P. 20400

ID $1^{\text {st }}$ Author: Ricardo, Jara-Ruiz / ORC ID: 0000-0001-7725-4138, Researcher ID Thomson: T-1532-2018, CVU CONACYT ID: 630276

ID $1^{\text {st }}$ Coauthor: Jesús, De La Cruz / ORC ID: 0000-0001-5295-6934, OPEN ID: 111669342951871883243, CVU CONACYT ID: 1117066

ID $2^{\text {nd }}$ Coauthor: Martín Eduardo, Rodríguez-Franco / ORC ID: 0000-0002-6804-4777, Researcher ID Thomson: T-15392018, CVU CONACYT ID: 660892

ID $3^{\text {rd }}$ Coauthor: Sergio Humberto, Delgado-Guerrero / ORC ID: 0000-0003-2521-5887, Researcher ID Thomson: V-17472018, CVU CONACYT ID: 240475

\section{Abstract}

In this paper, the particularities of applying parameterization in industrial machines corresponding to the manufacturing area are exposed and analyzed. For its development, the parameterized design of a die cutting machine is proposed as an object of study, which is formulated from the main elements considered of importance in the principle of operation, being necessary to carry out a prior investigation to analyze it and how the parameterization process influences. Parameterization is a quality of the components to adapt flexibly to the needs of the industry or sector, facilitating the redesign and manufacturing process, allowing the desired dimensional update or adjustment to be carried out only to the central component and the others are automatically adapted. Attending to the current needs and trends of the fourth industrial revolution, as well as establishing the benefits of this type of flexible design processes to expand their implementation to different industrial machines such as robot configurations.

Parameterization, Die cutting machine, Flexible manufacturing

\section{Resumen}

En el presente trabajo se expone y se analizan las particularidades de aplicar la parametrización en máquinas industriales correspondientes al área de manufactura. Para su desarrollo se plantea el diseño parametrizado de una máquina suajadora como objeto de estudio, el cual se formula a partir de elementos principales y considerados de importancia en el principio de funcionamiento siendo necesario realizar una investigación previa para analizar dicho principio y cómo influye el proceso de parametrización. El parametrizado es una cualidad de los componentes para adaptarse de forma flexible a las necesidades de la industria o sector, facilitando el proceso de rediseño y fabricación al permitir realizar la actualización dimensional o ajuste deseado únicamente al componente central y el resto de los elementos se adaptan de manera automática. Lo anterior atendiendo a las necesidades y tendencias actuales de la cuarta revolución industrial, así como el establecer los beneficios de este tipo de procesos de diseño flexibles para ampliar la implementación de los mismo a diferentes máquinas industriales como los son las configuraciones de robot.

Parametrización, Máquina suajadora, Manufactura flexible

Citation: JARA-RUIZ, Ricardo, DE LA CRUZ, Jesús, RODRÍGUEZ-FRANCO, Martín Eduardo and DELGADOGUERRERO, Sergio Humberto. Parametric design applied to die cutting machine. Journal of Systematic Innovation. 2021. 5-16: $14-19$

\footnotetext{
* Correspondence to Author (e-mail: ricardo.jara@utna.edu.mx)

$\dagger$ Researcher contributing as first author.
} 


\section{Introduction}

At present it is quite common to find applications in the industry where there is a need to make some improvements to the mechanisms in order to make adjustments, correct errors, increase production, etc .; For this reason it is necessary to expand or reduce the dimensions of the machine in general, that is where the concept of parametric design comes in, which allows a joint update considering the dimension and position of each of the components.

Creating parametric designs in 3D allows you to enter a series of variables or parameters, such as spatial limits or volumes to manipulate them through algorithms and thus obtain geometric designs in which everything is related to each other; The objective of parametric design is the automation of the process where it is sought to reduce or eliminate errors when editing the design.

For example, in a large assembly when having the need to modify the dimensions, it would have to be edited piece by piece, taking a great amount of time to edit, in addition to the risk of generating errors in the assembly, on the other hand, if the design has the parameterization, it would only be enough to change the dimension of one of its components and all the others would be adapted automatically.

The priority of this research being to facilitate the redesign process in existing models, taking into account the new trends in Industry 4.0.

\section{Industry 4.0}

The Industry 4.0 concept is associated with a new way of organizing production systems, from the conception of the product, the needs to optimize processes and the intensive use of new technologies, with the use of quality tools, as well as optimization of the processes allowing to achieve an increase in efficiency and competitiveness and adjusting to the personalized needs of the consumer (GARCÍA, 2017).

\section{Design}

Engineering design has been defined as "the process of applying the various techniques and scientific principles with the purpose of defining a device, a process or a system with sufficient details that allow its realization" (Norton., 2009).

\section{Parametric design}

Parametric CAD is responsible for assigning non-linear rules between the proportions of a design, through equations of any type, and at the same time establishing geometric relationships, seeking the functionality of the model or its aesthetics. When performing the parameterization of a $\mathrm{CAD}$, it is possible to change each of the measures that make up the design so that they can later be edited (BERNAL \& SALOMÓN, 2017).

\section{SolidWorks}

SOLIDWORKS ${ }^{\circledR}$ CAD software is a mechanical design automation application that enables designers to quickly sketch ideas, experiment with features and dimensions, and produce detailed models and drawings (Corporation, 1995-2015).

\section{Manufacture}

It is the process of converting raw materials into products. It also includes activities in which the manufactured product itself is used to make other products (Schmid, 2008).

\section{CAD systems}

Graphical analysis is performed using traditional drawing procedures or a CAD system, as is normally done in industry. For mechanism analysis, it is possible to use any of the various commercially available CAD systems. The most common 2D CAD system is AutoCAD. Although the commands differ from one system to another, all CAD systems have the ability to draw lines with designated lengths and angles with high precision. This is exactly the characteristic required by graphical mechanism analysis. In addition to increased accuracy, another advantage of CAD is that lines do not need to be scaled to fit on a piece of drawing paper. In the computer, the lines are drawn on an infinite size "virtual" paper. 
Also, the restricted drawing mode in three-dimensional modeling systems, such as Inventor, SolidWorks, and ProEngineer, are often extremely useful in plane kinematic analysis. Geometric constraints, such as length, perpendicularity, and parallelism, must be met when performing kinematic analysis. Such constraints are automatically executed in 3D modeling drawing mode (Myszka, 2012).

\section{Mechanism}

It is a device that transforms movement into a desirable pattern, and generally develops very low forces and transmits little power (Norton., 2009).

\section{Machine}

It is defined as a combination of resistant bodies arranged to make the mechanical forces of nature perform work accompanied by determined movements (Norton., 2009).

\section{Clamping process}

The die, or also called suaje, consists of a tool manufactured with a steel plate to bend, cut or mark materials such as fabric, paper, leather, etc. In reality, the cutting plates are metal strips sharpened on one side, and the bending plates are dull (Industriales, 2021).

\section{Methodology}

\section{Problem Statement}

Currently, there is a need for flexible designs that adapt to the needs and specifications of the user with the sole purpose of allowing optimization of the redesign process, reducing time and errors when some adjustment or dimensional update is required.

\section{General objective}

Implement a parametric design to a die-cutting machine that allows it to be flexibly adapted to the user's own needs, optimizing the process, reducing time and minimizing redesign errors.

\section{Particular objectives}

- $\quad$ Generate a previous diagnostic study.

- Develop a design based on the previously diagnosed study.
- $\quad$ Analyze areas for improvement.

- $\quad$ Redesign implementing improvements and parameterization.

Present results.

\section{Diagnosis}

As part of a previous study of the problem, it is decided to use a SWOT analysis as a tool to identify important points to consider for the planning and development of the proposal.

\section{SWOT analysis.}

\section{Strengths.}

- Reduction of times and costs in the design process of machines or mechanisms.

- Reduction of times and costs in the process of modifying already established designs.

- Identification of possible improvements.

- Identification of possible failures in the mechanisms.

- Modification of dimensions avoiding inconsistencies in the assembly document.

- Prevention of future errors when machining or assembling the design.

Weaknesses

Design time of the first assembly.

- Need to have the knowledge about parameterization in SolidWorks.

- Necessary mathematical equations.

- Greater complexity when designing.

Threats

- Default design customs in the industry.

- Standardization of dimensions in industrial machinery.

- Lack of training in industrial design upgrades and updates.

- Editing restrictions of some machines according to patents.

- Lack of training in industrial design upgrades and updates.

\section{Opportunities.}

- $\quad$ New updates in the industry.

- $\quad$ Industry 4.0 implementation.

- Micro-enterprises that have the need to adapt to the market.

- Companies dedicated to design. 


\section{Development}

A manual die cutting machine design is considered as a reference to establish the elements, mechanisms and dimensions used in the current market. Once this information is specified, the base design is generated using the specialized SolidWorks design software, considering an analysis of possible improvements to make the stamping process more productive.

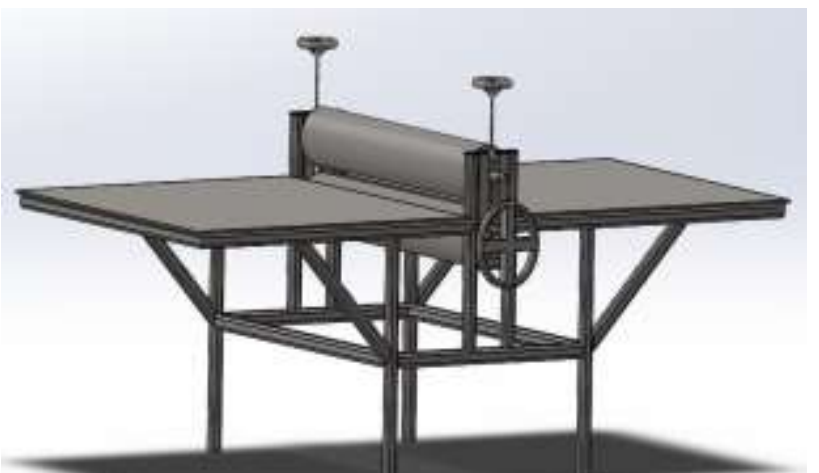

Figure 1 Manual die cutting machine design Source: Own Elaboration [SolidWorks]

After the evaluation of the improvements derived from the analysis, they continue with the implementation of the same, being that it is chosen to automate the machine to make the process of smoothing the material faster, more efficient, precise and safe for the user.

The automation is applied directly to the roller mechanism that acts as a material feeder for processing according to the operating principle of the die-cutting machine, for which a motor, a transmission and control system are contemplated for the change of rotation of the same.

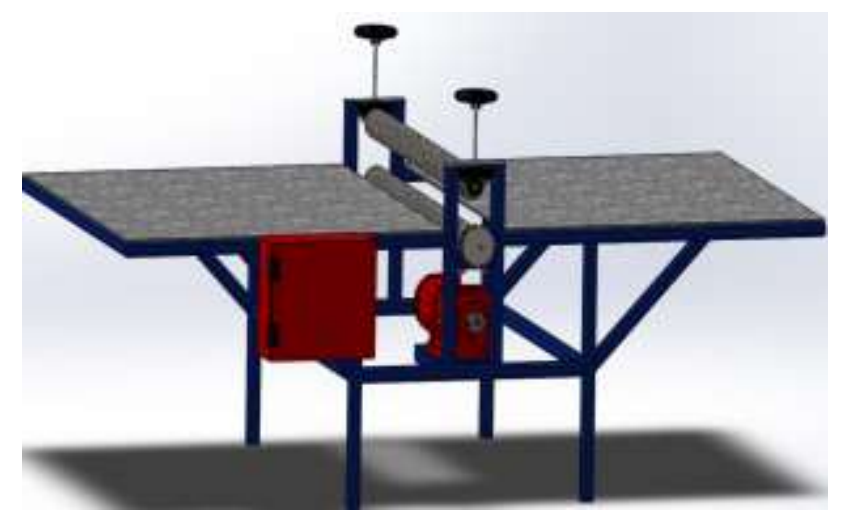

Figure 2 Automated die cutting machine Source: Own Elaboration [SolidWorks]

\section{Design parameterization}

To generate the design parameterization, the general operation of the object of study is analyzed to decide which component will act as the central element and which parameter is taken as a reference, being that it is detected that the dimension of the rollers (Figure 3) allows to control the capacity and size of material to be processed.

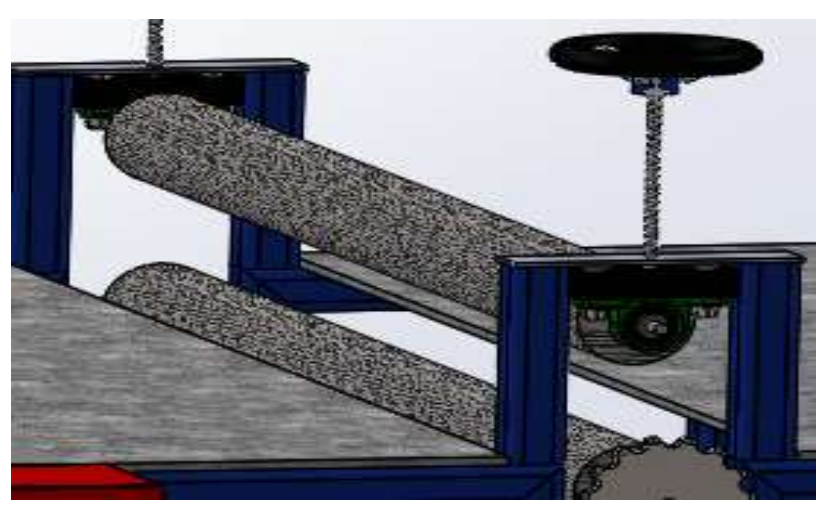

Figure 3 Die machine rollers Source: Own Elaboration [SolidWorks]

For this, the parameterization is applied in the arrow that supports the rollers, contemplating it is adjusted independently to adapt to the position of the bearings, so a relationship of equation is used (Figure 4).

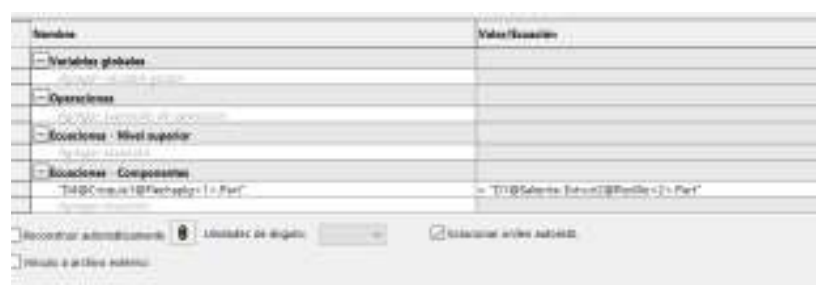

Figure 4 Arrow - Roller Parameterization. Source: Own Elaboration [SolidWorks]

In the case of the general assembly, two equations were used, one of them was applied to the main structure in relation to the length of the rollers and one more to adapt the plates corresponding to the new size of the structure (Figure 5).

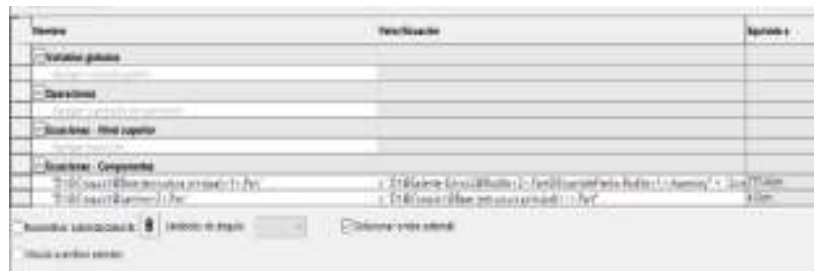

Figure 5 Roll parameterization - main structure Source: Own Elaboration [SolidWorks]

JARA-RUIZ, Ricardo, DE LA CRUZ, Jesús, RODRÍGUEZ-FRANCO, Martín Eduardo and DELGADO-GUERRERO, Sergio Humberto. Parametric design applied to die cutting machine. Journal of Systematic Innovation. 2021 
Constraints are one of the elements that must be taken into account when creating a parameterized industrial design since, if they are omitted, the design could take a different form or lose the relationships previously established.

In the process used to add dimensions, the pieces are considered as an independent element, however, the reality when creating a parametric assembly the components must work as part of a coordinated set. The restrictions were established from the mechanical position relations used in the assembly of the reference die cutting machine. The relationships or constraints used to achieve the purpose are mainly concentricity, coincident, parallel and distance.

A concentric relationship is applied between the date and bearing elements (Figure 6) essential to maintain the position when carrying out an update in the dimension of the rollers.

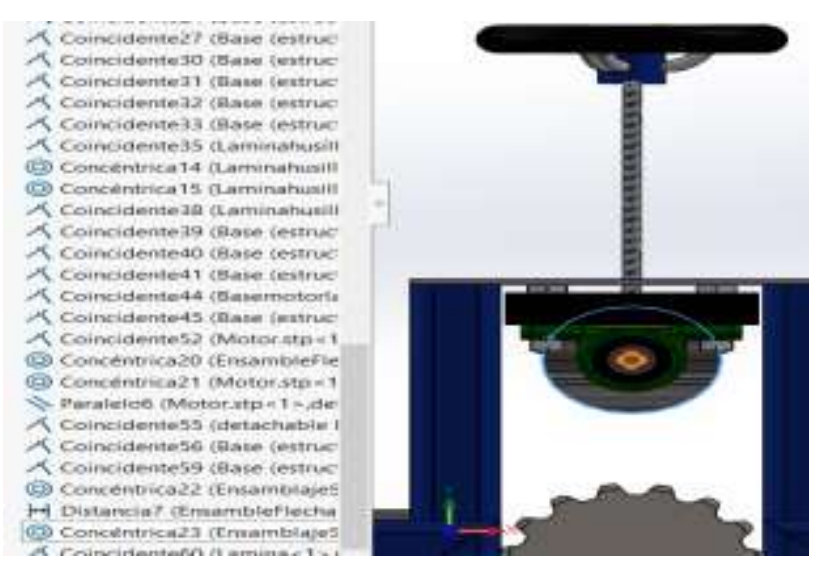

Figure 6 Concentric arrow-bearing relationship Source: Own Elaboration [SolidWorks]

In addition, a distance relationship between the roller and the internal profile of the structure (Figure 7) is considered, restricting a safe distance to avoid friction and wear between both elements.

When applying the parameterization, the components are adapted to the desired dimension of the rollers, respecting the assigned relationship in size and position automatically without being necessary to individually edit each element such as the structure, the plates, the $1 / 2$ inch arrow, etc. . (Figure 8 and 9).

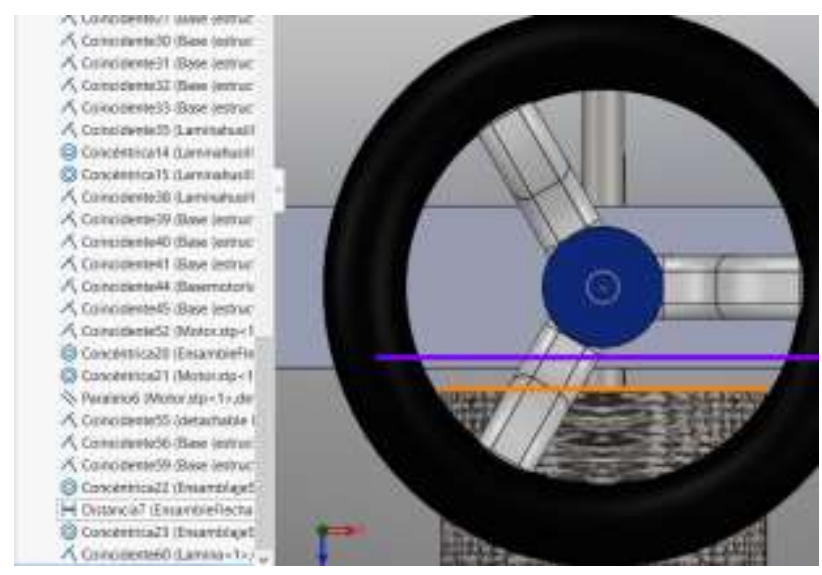

Figure 7 Relation between the end of the roller and the end of the profile

Source: Own Elaboration [SolidWorks]

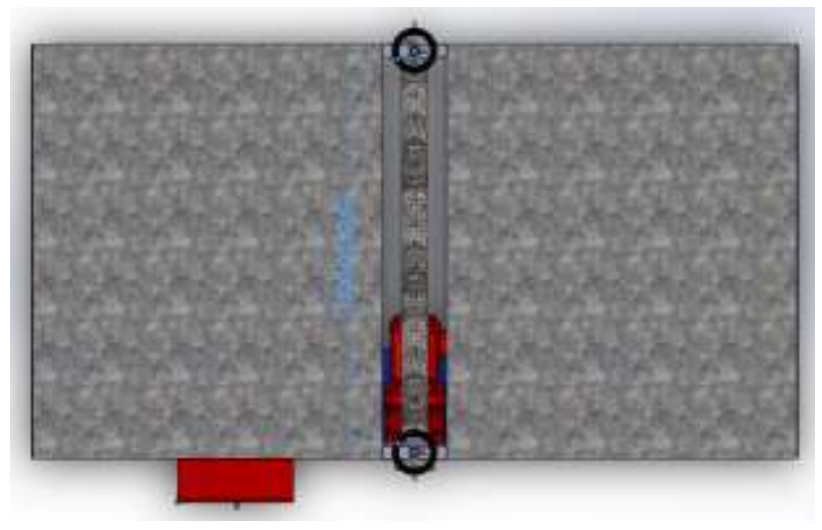

Figure 8 Parametric design of a 1.5 meter $(1500 \mathrm{~mm})$ roller die cutting machine.

Source: Own Elaboration [SolidWorks]

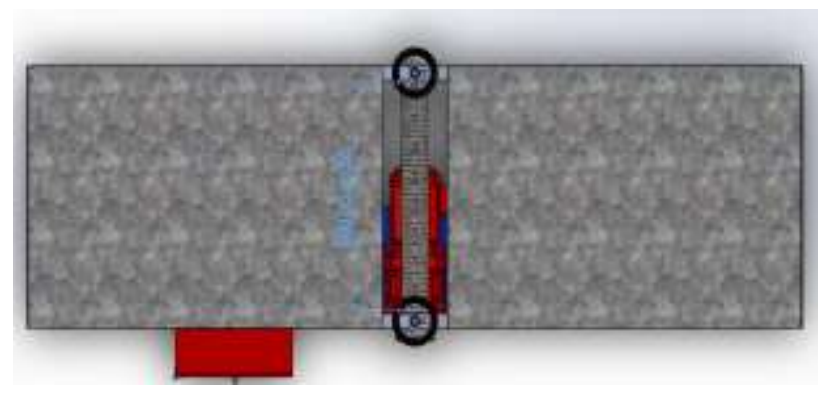

Figure 9 Parametric design of a 0.8 meter $(800 \mathrm{~mm})$ roller die cutting machine

Source: Own Elaboration [SolidWorks]

All the restrictions and equations applied to the design have the sole purpose of establishing a hierarchy and dependency based on parameters established between the components, respecting their position and assigned dimension, in this way an adequate and optimal parameterized model is guaranteed that allows reducing time and costs of editing on industrial machines. 


\section{Results}

With the implementation of the parameterization process in the design of the die cutting machine, it was possible to analyze the critical points and important areas for improvement to meet the objective of this project.

By concentrating all of the design editing in a single parameter corresponding to an element, it was possible to simplify the redesign process and reduce time between 30 and 40 percent compared to the conventional process. In addition, a general standardization of the different commercial models of this type of industrial machines is established in a single design based on the dimensions and location of the components necessary for their manufacture according to the user's requirements.

By providing this type of design with this capacity, the market field for said machinery can be expanded to be used not only in printing presses, but also in industrial companies where stamping is used.

The scope of this research goes beyond the results obtained from the application of parametric design in a die cutting machine, and its future implication in the design of industrial machines and flexible manufacturing is analyzed, so it would be convenient to apply the parameterization to designs of industrial robot configurations.

\section{Conclusions}

Industrial design knowledge plays an important role in generating a parameterized model, since a more extensive vision capable of identifying the components with the greatest influence on the design of any important machine is needed to establish the pertinent restrictions and the parameterization process.

The process of editing any design can become too complex, since an analysis would have to be carried out again to make the changes that you want to make, on the other hand, having a parameterized design of the machine reduces the process. to adjust the value of the key components, in this case the roller.
Parametric design is a scheme with great possibilities for industrial designs that provides different advantages when making modifications, either to obtain an improvement or by necessity, facilitating the redesign in any of its components without having to carry out an individual analysis again. of each mechanism or structure.

Studying the parameterization allowed detecting the need to update the stamping machines, since in recent years no improvements have been applied to commercially established designs, that is why the development of this project was carried out considering the applied methodologies in the industry and proving its innovation.

\section{References}

BERNAL, J. M., \& SALOMÓN, J. C. (2017). FABRICACIÓN DE PROTESIS TOMANDO EN CUENTA LA PARAMETRIZACIÓN. BOGOTA.

Corporation, D. S. (1995-2015). INTRODUCCIÓN A SOLIDWORKS. Waltham: Dassault Systemes SolidWorks Corporation.

GARCÍA, J. L. (2017). INDUSTRIA 4.0 ANÁLISIS, EVOLUCIÓN E IMPLICACIONES PARA EL EMPLEO. VALLADOLID.

Industriales, S. (26 de marzo de 2021). Suajes Industriales. Obtenido de https://www.suajesindustriales.com/blog/article s/proceso-de-suaje

Myszka, D. H. (2012). Máquinas y Mecanismos. México: PEARSON.

Norton., R. L. (2009). Diseño de maquinaria. México, D.F.: MC GRAW HILL.

Schmid, S. K. (2008). Manufactura, ingeniería y tecnología. Quinta edición. México: PEARSON EDUCACIÓN. 